\title{
Bioleaching and chemical leaching as an integrated process in the zinc industry
}

\author{
Adelson D. de Souza ${ }^{a}$, Pablo S. Pina ${ }^{b}$, Versiane Albis Leão ${ }^{b, *}$ \\ ${ }^{a}$ Votorantim Metais Zinc - Technologies Development Centre, BR 040, Km 274-Três Marias, MG 39205-000, Brazil \\ ${ }^{\mathrm{b}}$ Universidade Federal de Ouro Preto, Department of Metallurgical and Materials Engineering, Núcleo de Valorização de Materiais Minerais, \\ Praça Tiradentes, 20, Centro, Ouro Preto, MG 35400-000, Brazil
}

Received 9 October 2006; accepted 14 December 2006

Available online 20 February 2007

\begin{abstract}
This work sought to integrate bioleaching and chemical leaching as a cost-effective process to treat zinc sulphides. The continuous bioleaching of a sphalerite concentrate, assaying $51.4 \% \mathrm{Zn}, 1.9 \% \mathrm{~Pb}, 31.8 \% \mathrm{~S}$ and $9.0 \% \mathrm{Fe}$ with mesophile iron and sulphur-oxidizing bacteria followed by chemical leaching of the bioleaching residue were assessed. In the bioleaching step, the first reactor was used to produce $\mathrm{Fe}(\mathrm{III})$ concentrations as high as $20 \mathrm{~g} / \mathrm{L}$. This solution was fed to the subsequent bioleaching reactors to oxidize sphalerite. It was possible to achieve $30 \%$ zinc extraction for $70 \mathrm{~h}$ residence time. In chemical leaching experiments, carried out with the residue of the bioleaching step, the effects $\mathrm{Fe}_{\text {total }}$ and acidity on zinc extraction were studied. It was noticed that Fe(III) concentrations over $12 \mathrm{~g} / \mathrm{L}$ did not affect zinc recoveries. Furthermore, the higher the acidity, the larger the zinc recovery, for experiments carried out up to $181 \mathrm{~g} / \mathrm{L}$ sulphuric acid. The results have demonstrated that it is possible to devise a new process capable of achieving $96 \%$ zinc extraction, similarly to the conventional roasting-leaching-electrolysis process.
\end{abstract}

(c) 2007 Elsevier Ltd. All rights reserved.

Keywords: Bioleaching; Sphalerite; Ferric iron; Ferrous iron; Zinc

\section{Introduction}

Primary zinc production can be carried out by basically two different routes: (i) the hydrometallurgical process proposed in 1916 and (ii) the imperial smelting process first introduced in Swansea (UK) in the 1960s. The hydrometallurgical process accounts for some $85 \%$ of the primary zinc production. Conversely, the imperial smelting process currently represents less than $15 \%$ of the world's zinc production and has been progressively abandoned. Other technologies include zinc pressure leaching (Cominco Trail, Flin Flon and Kidd Creek), atmospheric direct leaching (Outokumpu Kokkola and Onsan Korea Zinc), the integrated sulphide-silicate process (Votorantim Zinc) and

\footnotetext{
${ }^{*}$ Corresponding author. Tel./fax: +55 3135591561.

E-mail addresses: adelson@vmetais.com.br(A.D.de Souza),versiane@ demet.em.ufop.br (V.A. Leão).
}

the solvent extraction process (Skorpion Zinc) (Souza, 2005).

The traditional hydrometallurgical production of zinc from its sulphides comprises roasting, leaching and electrolysis (Feneau, 2002), namely the RLE process. This process was devised to treat zinc sulphide concentrates and basically includes a zinc sulphide roasting step to produce $\mathrm{ZnO}$ and sulphur dioxide. The calcine $(\mathrm{ZnO})$ is sent to leaching followed by the purification and electrolysis steps where special high-grade (SHG) zinc is produced (Fig. 1).

As far as alternative technologies are concerned, two similar routes have been proposed in the 1970 s to leach zinc sulphides: (i) Direct Atmospheric Leaching (Svens et al., 2003) in which zinc sulphide concentrates are leached directly with a ferric iron solution (produced during the leaching step of the RLE process); and (ii) Pressure Leaching that adopts a similar approach except that leaching is carried out in autoclaves (14-15 atm oxygen pressure). 


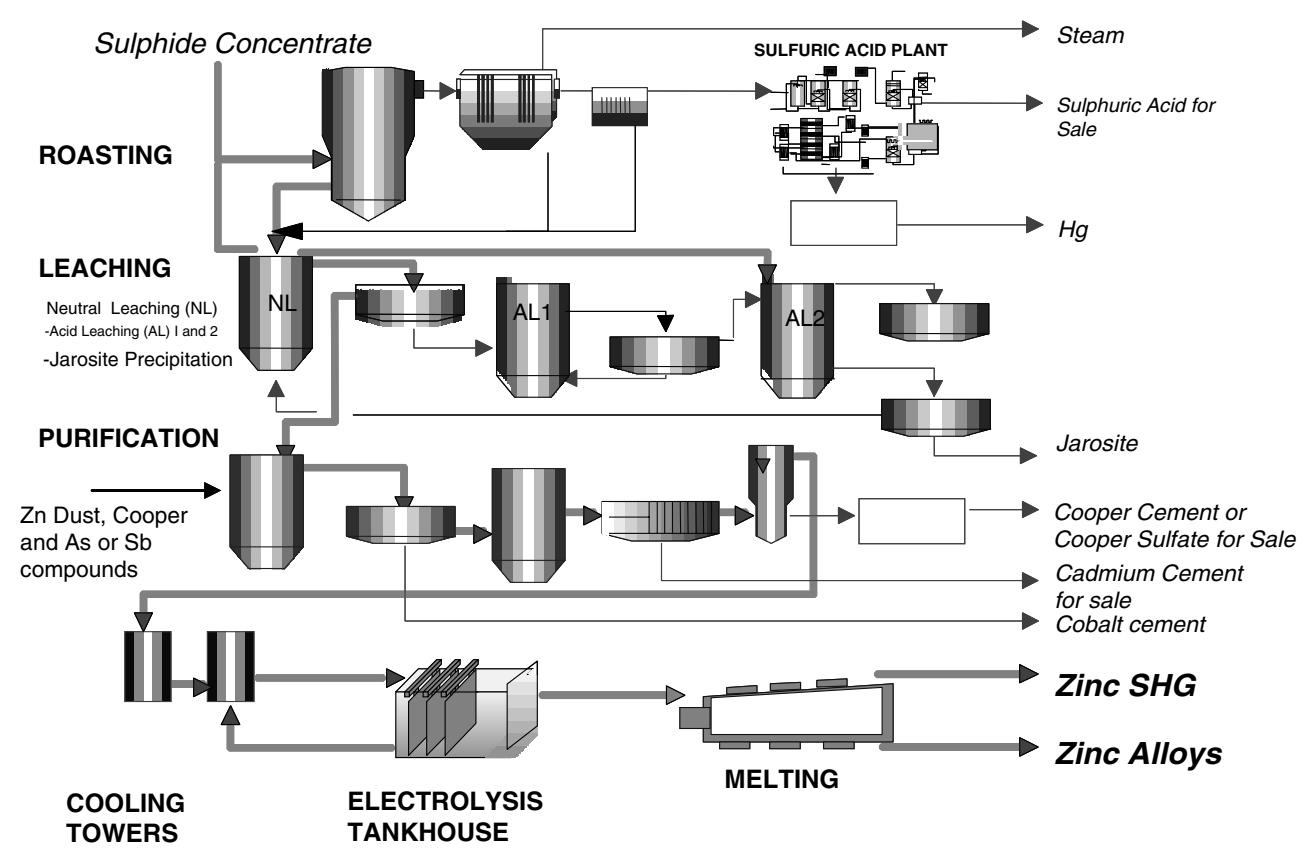

Fig. 1. Process flow sheet for zinc production by the roasting-leaching-electrolysis (RLE) route.

The high oxygen pressure achieved in the latter enables fast concentrate dissolution: $90 \mathrm{~min}$ is the standard residence time. Conversely, the direct atmospheric leaching process requires around $24 \mathrm{~h}$ for leaching and therefore larger reactors are required as compared to pressure leaching plants (Svens et al., 2003).

$\mathrm{ZnS}$ leaching by $\mathrm{Fe}(\mathrm{III})$ can be represented as follows:

$\mathrm{Fe}_{2}\left(\mathrm{SO}_{4}\right)_{3}(\mathrm{aq})+\mathrm{ZnS}(\mathrm{s})$

$$
\rightarrow 2 \mathrm{FeSO}_{4}(\mathrm{aq})+\mathrm{ZnSO}_{4}(\mathrm{aq})+\mathrm{S}^{\circ}(\mathrm{s})
$$

Gaseous oxygen (93-98\%) oxidizes the ferrous iron produced by Eq. (1) to Fe(III):

$$
\begin{aligned}
& 2 \mathrm{FeSO}_{4}(\mathrm{aq})+\mathrm{H}_{2} \mathrm{SO}_{4}(\mathrm{aq})+0.5 \mathrm{O}_{2}(\mathrm{~g}) \\
& \quad=\mathrm{Fe}_{2}\left(\mathrm{SO}_{4}\right)_{3}(\mathrm{aq})+\mathrm{H}_{2} \mathrm{O}(\mathrm{l})
\end{aligned}
$$

The overall leaching reaction is

$$
\begin{aligned}
& \mathrm{ZnS}(\mathrm{s})+\mathrm{H}_{2} \mathrm{SO}_{4}(\mathrm{aq})+0.5 \mathrm{O}_{2}(\mathrm{~g}) \\
& \quad \rightarrow \mathrm{ZnSO}_{4}(\mathrm{aq})+\mathrm{H}_{2} \mathrm{O}(\mathrm{l})+\mathrm{S}^{\circ}(\mathrm{s})
\end{aligned}
$$

The economics of these new processes is determined mainly by the oxygen consumption, a relatively expensive raw material. Furthermore, the elemental sulphur produced during $\mathrm{ZnS}$ oxidation by $\mathrm{Fe}(\mathrm{III})$ is not easily commercialised due to its usual high impurities content. Notwithstanding, capital costs are lower and sulphur dioxide is not produced in both processes. As a result, the latter are considered more environmentally friendly as compared to the RLE process.

Bioleaching can also be utilized to oxidize zinc sulphides (Boon et al., 1998; Brierley and Brierley, 2001). Although slower than chemical leaching, bioleaching of $\mathrm{ZnS}$ does not require gaseous oxygen since $\mathrm{Fe}(\mathrm{II})$ oxidation is carried out by the microorganisms. In this case, air is required for bacterial respiration. A mixed process - bioleaching and chemical leaching - would therefore result in the reduction of the overall oxygen consumption while circumventing the high residence times observed in the complete bioleaching of zinc sulphides. This approach is currently been applied at the Sao Bento gold mine (Brazil) (Carmo et al., 2001) to reduce oxygen requirements in the pressure oxidation of refractory gold ores. The present work sought to apply this approach to leach zinc sulphides so that a new contribution to the technological development in the zinc industry is proposed. This was achieved by the application of aerobic acidophilic bacteria that oxidises ferrous iron and also reduces the production of elemental sulphur, since the sulphide ion is directly oxidized to sulphate. The first step comprised the partial bioleaching of concentrate followed by chemical leaching of the bioleaching residue.

\section{Experimental}

\subsection{Bioleaching experiments}

Continuous bioleaching experiments were carried out in a series of three bioreactors (R2, R3 and R4), the first one with a $20 \mathrm{~L}$ volume and the following two with a capacity of $12 \mathrm{~L}$ each (Fig. 2). This system was fed by (i) a pulp formed by the $\mathrm{ZnS}$ concentrate and sulphuric acid and (ii) a biologically produced ferric iron solution containing mesophile-acidophilic bacteria ( $\mathrm{Fe}(\mathrm{II})$ biooxidation reactor, R1). As shown in Fig. 2, a $20 \mathrm{~g} / \mathrm{L}$ a ferrous sulphate solution was pumped $(3 \pm 0.2 \mathrm{~mL} / \mathrm{min})$ to reactor $\mathrm{R} 1$ and the produced ferric iron solution was fed to reactor R2 by gravity where it joined with the zinc sulphide slurry 


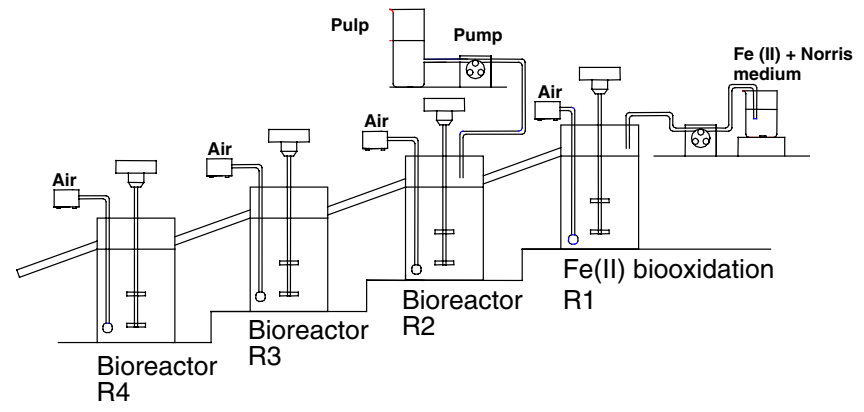

Fig. 2. Experimental set-up for the continuous bioleaching experiments. Bioreactor R2 has a $20 \mathrm{~L}$ volume whereas reactors R1, R3 and R4, have $12 \mathrm{~L}$ each.

pumped at a flowrate of $8.6 \pm 0.3 \mathrm{~mL} / \mathrm{min}$. The experiments were carried out at $307 \mathrm{~K}\left(34^{\circ} \mathrm{C}\right)$ and $31.41 \mathrm{rad} \mathrm{s}^{-1}$ $\left(300 \mathrm{~min}^{-1}\right)$ in a temperature-controlled room.

The microorganisms studied were isolated from the Morro Agudo Mine (Votorantim Zinc) and are currently being characterized using molecular biology techniques. They were cultured aerobically in a selective medium for at least 4 years in the presence of both $\mathrm{Fe}(\mathrm{II})$ and zinc sulphide, at $307 \mathrm{~K}\left(34^{\circ} \mathrm{C}\right)$ (Daman et al., 2002). The growth medium used (Norris) has the following composition: $\left(\mathrm{NH}_{4}\right)_{2} \mathrm{SO}_{4}: 0.2 \mathrm{~g} / \mathrm{L} ; \mathrm{MgSO}_{4} \cdot 7 \mathrm{H}_{2} \mathrm{O}: 0.4 \mathrm{~g} / \mathrm{L}$ and $\mathrm{K}_{2} \mathrm{HPO}_{4}: 0.1 \mathrm{~g} / \mathrm{L}$ and distilled water, at $\mathrm{pH} 1.8-2.0$. Iron (II) $\left(\mathrm{FeSO}_{4} \cdot 7 \mathrm{H}_{2} \mathrm{O}\right)$ was provided as a substrate for bacterial growth. Cell counts were assessed by direct counting in a Neubauer chamber, placed in a phase contrast microscopy (Leica).

The zinc concentrate assayed $51.4 \% \mathrm{Zn}, 1.9 \% \mathrm{~Pb}, 31.8 \%$ $\mathrm{S}$ and $9.0 \% \mathrm{Fe}$ and with sphalerite accounting for $95 \%$ of the mineralogical phase present in the solids. Particle size was $100 \%-44 \mu \mathrm{m}$ (325\# tyler) and prior being fed to the continuous bioleaching set-up, the concentrate was dried overnight.

Throughout the experiments, a pulp with $10 \%$ solids was fed to reactor R2. This solid percentage remained fairly constant throughout the reactors. The pulp was aerated with oil-free compressed air by ceramic bubblers. During the experiments, there was a progressive blockage of these bubblers. The dissolved oxygen concentration (dissolved oxygen meter, Digimed DM 4) was used to trace this blockage and as soon as the dissolved oxygen concentration dropped to less than $1 \mathrm{mg} / \mathrm{L}$, the bubblers were replaced.

During the continuous experiments, zinc extractions were determined by Eq. (4):

$\mathrm{Zn} \cdot \operatorname{extraction}(\%)=\frac{C_{\mathrm{Zn}} \cdot \mathrm{Qs}}{1000 \cdot \mathrm{Qe} \cdot(\% \mathrm{Sp}) \cdot(\% \mathrm{Zn})}$

where Qe is the pulp flowrate fed to the system $(\mathrm{mL} / \mathrm{min})$; Qs, the pulp flowrate leaving the system $(\mathrm{mL} / \mathrm{min}) ; \% \mathrm{Sp}$, the pulp density entering the system; $\% \mathrm{Zn}$ is the zinc concentration in the concentrate and $C_{\mathrm{Zn}}$, the zinc concentration in solution $(\mathrm{g} / \mathrm{L})$.

\subsection{Chemical leaching experiments}

Chemical leaching studies were carried out batchwise, at $368 \mathrm{~K}\left(95^{\circ} \mathrm{C}\right)$, in a $2 \mathrm{~L}$ glass reactor mechanically stirred $\left(31.41 \mathrm{rad} \mathrm{s}^{-1}\left(300 \mathrm{~min}^{-1}\right)\right)$ in which oxygen $(99 \%)$ was bubbled at a flow rate of $1-2 \mathrm{~L} / \mathrm{min}$. The bioleaching residue used in the chemical leaching studies assayed $47-51 \%$ $\mathrm{Zn}$ and $5.0 \mathrm{Fe}$ and the particle size distribution was $90 \%$ below $44 \mu \mathrm{m}$ (325\# tyler). The pulp (10\% solids) was produced by mixing the solid residue of the bioleaching step with a zinc-process solution formed by the overflow from the acid leaching (RLE process) of zinc ferrites $(\mathrm{ZnO}$. $\mathrm{Fe}_{2} \mathrm{O}_{3}$ ) and spent solution from the zinc electrolysis step. Unless otherwise stated, this solution contained 14-15 g/ L Fe(III), 90-100 g/L Zn and 170-181 g/L free acidity.

\subsection{Chemical analysis}

Concentrate samples were dissolved by treating $0.25 \mathrm{~g}$ in

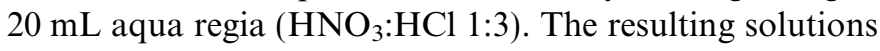
were then filtered and diluted to $1000 \mathrm{~mL}$ with distilled water prior to analysis. Total iron $\left(\mathrm{Fe}_{\mathrm{T}}\right)$ and zinc were analysed by atomic absorption spectrometry in a Perkin-Elmer Analyst 100 device. Fe(II) solution concentrations were determined regularly by titration with potassium dichromate in a Schott Titroline automated titrator. Fe(III) was assessed by the difference between $\mathrm{Fe}_{\mathrm{T}}$ and $\mathrm{Fe}(\mathrm{II})$ concentrations. Eh (Digimed) against a platinum electrode with a $\mathrm{Ag} / \mathrm{AgCl}$ reference electrode, and $\mathrm{pH}$ (Hanna Instruments) were measured ( $\mathrm{pH}$ was also corrected) on a daily basis. Acidity was determined by titration with sodium carbonate in the presence of bromocresol green as indicator. The interference of iron was removed with potassium iodide and sodium thiosulfate.

\subsection{Scanning electron microscopy}

The morphological features of the concentrate, the leach residues and the reaction products formed during bioleaching were studied by SEM-EDS. The particles investigated were filtered and observed as powder or mounted in epoxy resin and then polished to a flat, mirrored surface. Afterwards, samples were carbon coated and then examined with a JEOL JSM 501 SEM microscope. Energy dispersive $\mathrm{X}$-ray spectroscopy (EDS) was used for elemental analysis.

\section{Results}

\subsection{Continuous bioleaching experiments}

The concept adopted in the present work was to biologically oxidize $\mathrm{Fe}(\mathrm{II})$ and to feed the $\mathrm{Fe}(\mathrm{III})$ produced solution along with the iron oxidizing bacteria to the bioreactors i.e., the first reactor (R1) was used to biologically oxidize $\mathrm{Fe}(\mathrm{II})$ while the subsequent reactors, to bioleach zinc sulphide. In reactor $\mathrm{R} 1$, a constant bacterial population (around $4 \times 10^{8}$ cells $/ \mathrm{mL}$ ) was also produced, 
which was fed to the downstream reactors (R2, R3 and R4) where the concentrate was oxidized.

Fig. 3a presents both ferrous and ferric iron concentrations at the exit of reactor R1. As shown in Fig. 3a the bacteria oxidized almost all ferrous iron fed to R1, and therefore $\mathrm{Fe}(\mathrm{III})$ content was similar to total iron concentration. Iron-oxidizing bacteria such as those of the genera Acidithiobacillus and Leptospirillum catalyse Fe(II) oxidation, increasing the rate of oxidation as high as five orders of magnitude (Lacey and Lawson, 1970). As will be discussed in the following paragraphs, the $\mathrm{Fe}(\mathrm{III})$ concentration is important since the indirect mechanism plays a key role in zinc sulphide bioleaching (Crundwell, 2001). It is proposed that ferrous iron oxidation by Acidithiobacillus ferrooxidans (one of most the likely mesophiles in the bioleaching reactors) occurs outside the cell's outer membrane while electrons are taken from Fe(II) by cytochrome $\mathrm{C} 2$ and transferred to rusticyanin which accounts for electron transport inside the bacterium cell (periplasm). Sulphate seems to participate in the oxidation mechanism complexing $\mathrm{Fe}(\mathrm{II})$ and facilitating electrons transfer to the cells (Nemati et al., 1998).
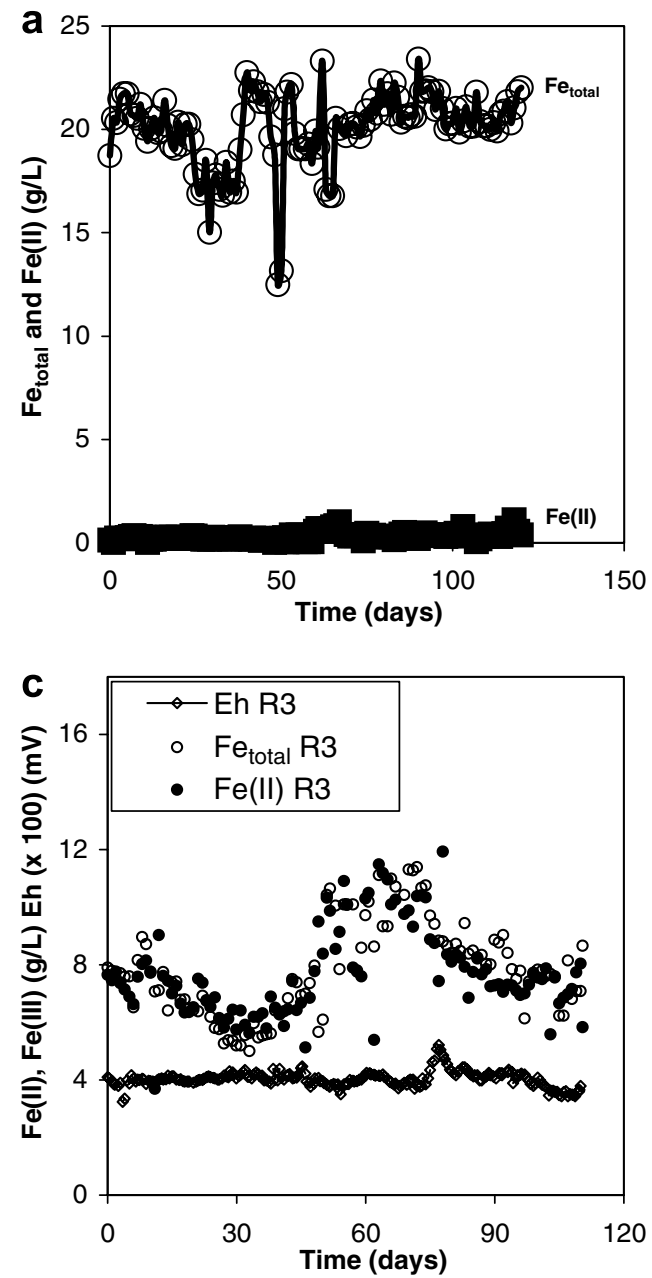

While $\mathrm{Fe}(\mathrm{II})$ is a substrate for bacterial growth, it has been suggested that $\mathrm{Fe}(\mathrm{III})$ concentrations above $10 \mathrm{~g} / \mathrm{L}$ adversely affect sulphide bioleaching (Nemati and Harrison, 1999). This was not observed in the present work as the bacteria could tolerate $20 \mathrm{~g} / \mathrm{L} \mathrm{Fe}$ (III). It is likely that the mixed population present in the bioleaching experiment accounted for this behaviour, as the limiting effect of iro$\mathrm{n}$ (III) on the $\mathrm{Fe}(\mathrm{II})$ biooxidation is defined by the kind of bacteria studied (Nemati et al., 1998; Nemati and Harrison, 1999).

Reactors R2, R3 and R4 were fed (through reactor R2, Fig. 2) separately with the $20 \mathrm{~g} / \mathrm{L} \mathrm{Fe(III)} \mathrm{solution} \mathrm{(plus}$ bacteria) produced in reactor $\mathrm{R} 1$ and a sphalerite pulp $(10 \%$, at $\mathrm{pH} 1.8)$, so that zinc dissolution occurred. Therefore, the $\mathrm{Fe}(\mathrm{III})$ solution was diluted to values around $8 \mathrm{~g} /$ L, approximately (Fig. 3b-d). Between the 46th and 72nd day, the $\mathrm{Fe}$ (III) solution flowrate was doubled which resulted in the increase of the iron concentration in the reactor to $10-12 \mathrm{~g} / \mathrm{L}$, as depicted in Fig. 3b-d. After the 72nd day, the Fe(III) solution flowrate was returned to its standard value and the total iron concentration was returned to $8 \mathrm{~g} / \mathrm{L}$. These iron concentrations are slightly
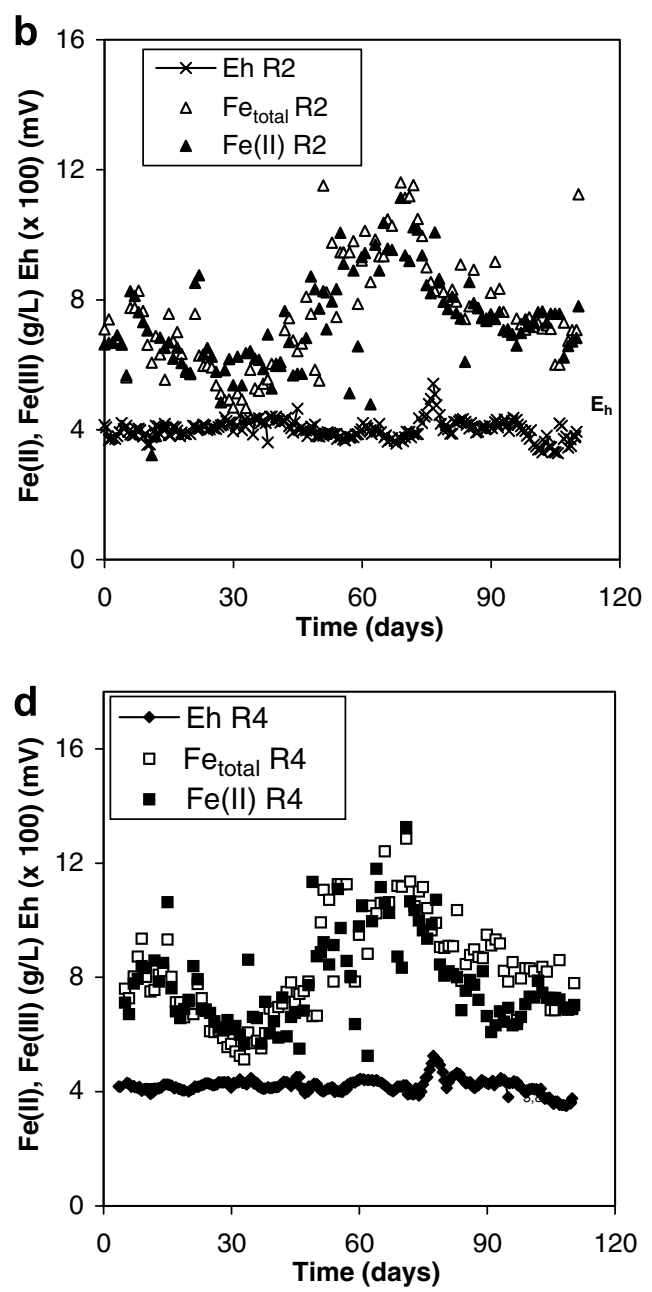

Fig. 3. $\mathrm{Fe}_{\text {total }}, \mathrm{Fe}(\mathrm{II})$ and Eh concentrations in the biooxidation reactor (a) and in the sphalerite bioleaching reactors R2 (b), R3 (c) and R4 (d). 
higher than that applied by Pani et al. (2003) which observed $84 \%$ zinc extractions, after $408 \mathrm{~h}$ for a slurry containing 5-6 g/L Fe. Despite the variations in iron concentration, zinc dissolution was not affected as will be discussed in the next paragraphs.

Unlike the reactor where $\mathrm{Fe}(\mathrm{II})$ was oxidized, the zinc sulphide bioleaching reactors (R2, R3 and R4) show different behaviour regarding iron concentrations. Fig. 3b-d shows that the $\mathrm{Fe}(\mathrm{II})$ concentration is close to the $\mathrm{Fe}_{\text {total }}$ content and, as a result, indicates that almost all Fe(III) entering the bioleaching step was reduced to $\mathrm{Fe}(\mathrm{II})$ during $\mathrm{ZnS}$ oxidation (Eq. (1)). These results suggest that the biological oxidation of $\mathrm{Fe}(\mathrm{II})$ limits the overall process i.e. the $\mathrm{Fe}(\mathrm{II})$ biooxidation rate (similar to the biological production of $\mathrm{Fe}(\mathrm{III})$ ) is lower than the $\mathrm{Fe}(\mathrm{III})$ consumption by sphalerite leaching. Therefore, the solution's ferrous iron concentration was high and the ferric iron content was small. This is because sphalerite leaching by Fe(III) is relatively rapid specially when elemental sulphur is oxidized directly to sulphate, as observed (Crundwell, 1988). Despite the variations in iron concentration, the potential

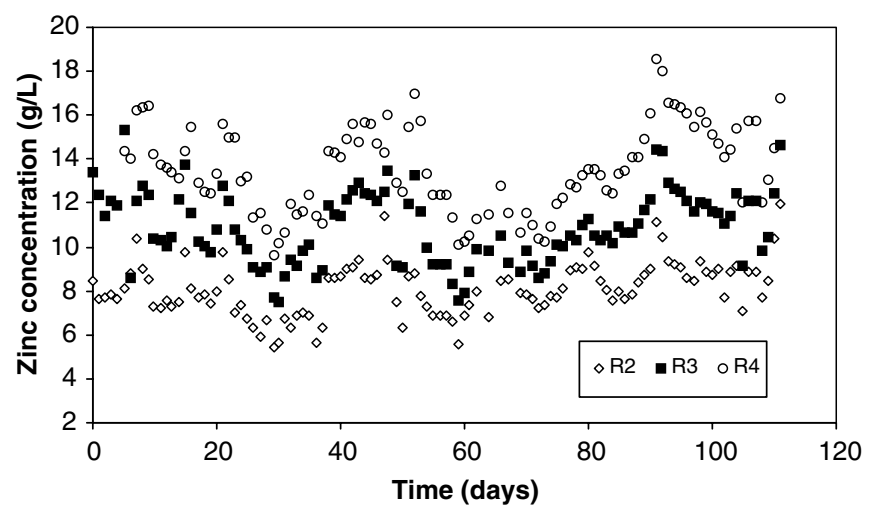

Fig. 4. Zinc concentration profiles during continuous bioleaching of a zinc sulphide concentrate. of the pulp remained fairly constant at around $400 \mathrm{mV}$ $(\mathrm{Ag} / \mathrm{AgCl})($ Fig. $3 \mathrm{~b}-\mathrm{d})$ thorough the whole experiment.

Zinc concentration in reactors $\mathrm{R} 2, \mathrm{R} 3$ and $\mathrm{R} 4$ is presented in Fig. 4. Average zinc concentration was $8.1 \mathrm{~g} / \mathrm{L}$ in $\mathrm{R} 2,10.7 \mathrm{~g} / \mathrm{L}$ in $\mathrm{R} 3$ and $13.5 \mathrm{~g} / \mathrm{L}$ in $\mathrm{R} 4$. The higher extraction in reactor $\mathrm{R} 2$ can be ascribed to the higher volume of this reactor $(20 \mathrm{~L})$, which resulted in a $40 \mathrm{~h}$ residence time compared to reactors 3 and $4(20 \mathrm{~h}$ residence time each). More importantly, reactor R2 received the $\mathrm{Fe}(\mathrm{III})$ solution produced in the biooxidation reactor (R1) while iron fed to reactors 3 and 4 was basically Fe(II) which needed to be biooxidized to $\mathrm{Fe}(\mathrm{III})$ prior to $\mathrm{ZnS}$ dissolution. This behaviour is reflected in zinc extractions, which is the greatest in reactor R2 $(\sim 15 \%)$. Overall extractions were above $25 \%$ (reactor R4) up to the 55th day. These extractions were achieved for a $60 \mathrm{~h}$ residence time. Following, a decrease in zinc concentration was observed up to the 70th day due to technical problems in the continuous system. After proper corrections and the increase of the residence time to $70 \mathrm{~h}$ (from the $72 \mathrm{nd}$ day onward), zinc extractions started to increase once more, reaching 30\% around the 90th day. These figures suggest faster dissolution than those previously reported (Pani et al., 2003), in which $400 \mathrm{~h}$ were required for $83 \%$ zinc extraction. However, the authors have not provided sufficient data for a direct comparison between both works.

One advantage of bioleaching is that the microorganisms are usually able to oxidize the elemental sulphur produced during $\mathrm{ZnS}$ oxidation (Eq. (2)) and therefore sulphate ions instead of elemental sulphur is produced during bioleaching. As a result, the latter does not cover the unleached $\mathrm{ZnS}$ particles. This can be observed in Fig. 5a which shows a SEM image of the leaching residue of the continuous bioleaching. The EDS spectrum (Fig. 5b) of the latter indicated $68.9 \% \mathrm{Zn}$ and $29.6 \% \mathrm{~S}$ (weight percent) which is consistent with a $\mathrm{ZnS}$ particle not covered by elemental sulphur as suggested by Fig. 5a. Furthermore, batch experiments were also carried out to confirm the
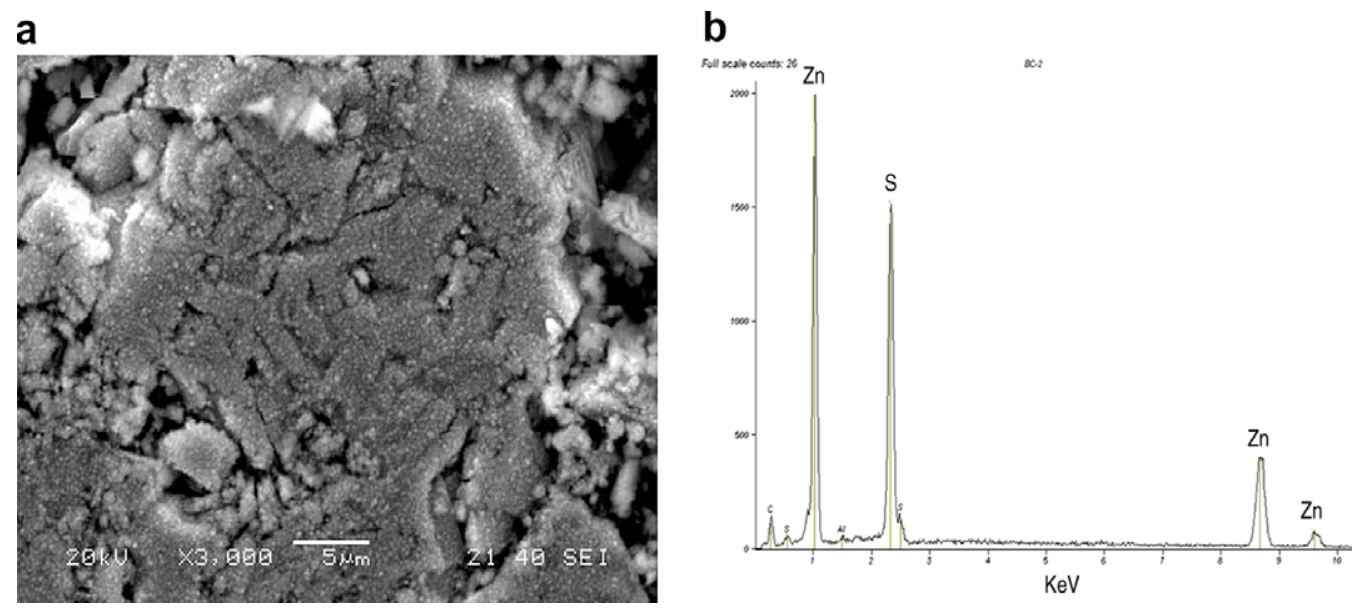

Fig. 5. Microphotograph (a) and EDS spectrum of the bioleaching residue. EDS results indicates the following composition: $68.9 \% \mathrm{Zn} ; 29.6 \% \mathrm{~S} ; 0.64 \% \mathrm{Al}$ (weight percentage). 
absence of elemental sulphur covering the bioleaching residue for different stages of leaching (Fig. 6). These experiments were performed with the same concentrate used in the continuous study and bacteria collected at the exit of the system (reactor R4). Fig. 6a shows a SEM image of the zinc concentrate before bioleaching started. Fig. $6 \mathrm{~b}$ and $\mathrm{c}$ shows the bioleaching residue after $25 \%$, and $50 \%$ zinc extractions, respectively. A progressive degradation of the sulphide surface can be seen as bioleaching proceeds.

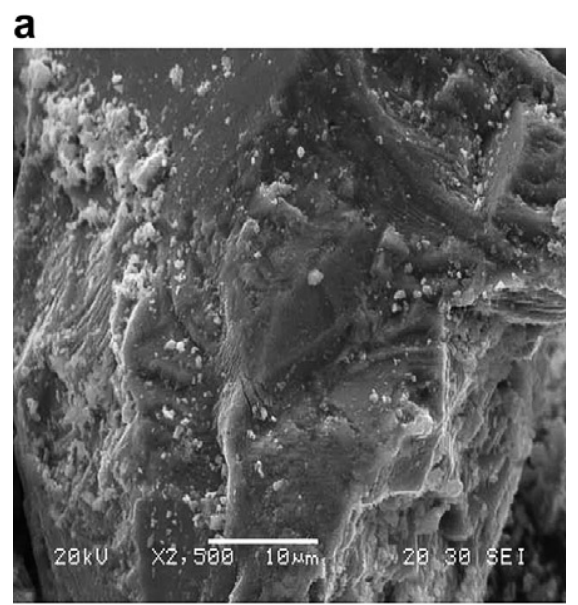

b

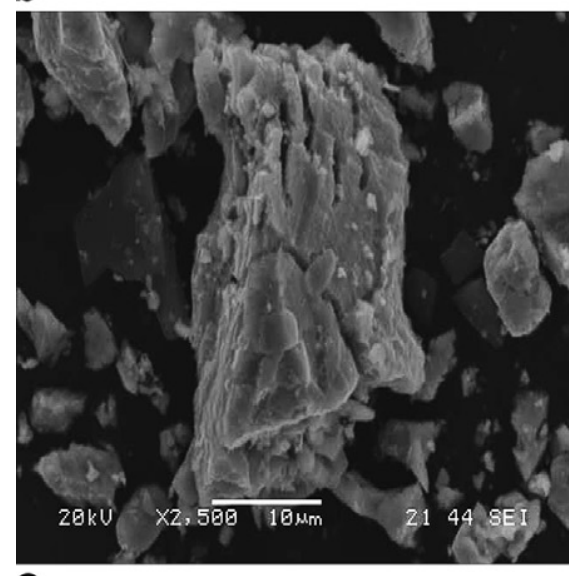

C

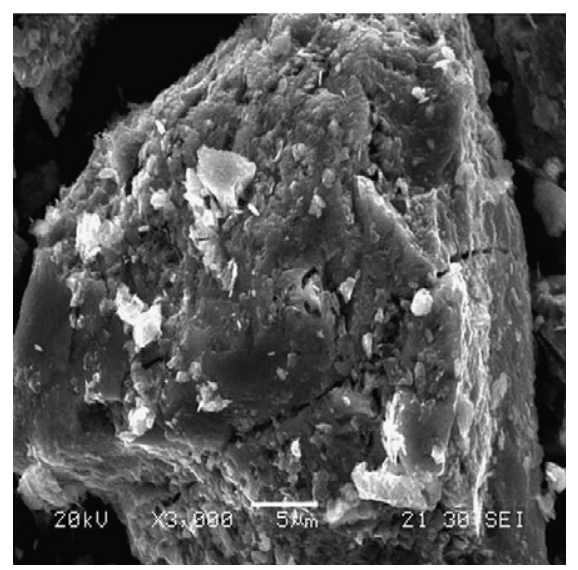

Fig. 6. SEM images of the zinc sulphide concentrate before (a) and after $25 \%$ (b) and $50 \%$ (c) zinc bioleaching. Experimental conditions $\mathrm{pH}=1.8$; $10 \%$ solids; $307 \mathrm{~K}\left(34^{\circ} \mathrm{C}\right), 2.0 \mathrm{gFe} / \mathrm{L}$.
These surfaces are not covered by a sulphur layer regardless the stage of bioleaching. This suggests that the bacteria were able to oxidize the elemental sulphur produced by $\mathrm{Fe}(\mathrm{III})$ oxidation. Furthermore, $\mathrm{pH} 1.80$ avoided the precipitation of jarosite, which could also cover the solid surface. Therefore, Figs. 5 and 6 show that the bioleaching residue is formed basically by partially shrunk ZnS particles. These results are in agreement with those observed by Fowler and Crundwell (1999) which noticed that elemental sulphur was present in the mineral surface when the bacterial population was low. However, as long as the bacterial population increased, the elemental sulphur started to be leached.

Despite microorganism's ability to oxidise elemental sulphur (the direct mechanism), Fe(II) biooxidation should not be overlooked. The indirect mechanism is very important during sphalerite bioleaching (Boon, 1996; Fowler and Crundwell, 1999). This is consistent with the results observed in the present work where reactor R2 received a ferric iron solution (produced in R1) resulting in the largest zinc dissolution of the continuous system as compared to the R3 and R4 reactors. The combined effect of both mechanisms has likely occurred during the continuous bioleaching of the concentrate whereby overall zinc extractions of up to $30 \%$ could be accomplished in a $70 \mathrm{~h}$ residence time.

\subsection{Chemical leaching studies}

The chemical leaching step can be described by Eqs. (1)(3) i.e. zinc dissolution is performed by $\mathrm{Fe}(\mathrm{III})$. Another important feature of zinc sulphide leaching is that sphalerite can also be dissolved by $\mathrm{H}^{+}$(Dutrizac and MacDonald, 1978; Schippers and Sand, 1999) therefore, the free acidity in the process solution must also be considered. The effects of these two parameters on zinc sulphide leaching are discussed next.

The effect of the iron content of the process's leaching solution on the zinc extraction from the partially bioleached material is presented in Fig. 7. Greater zinc

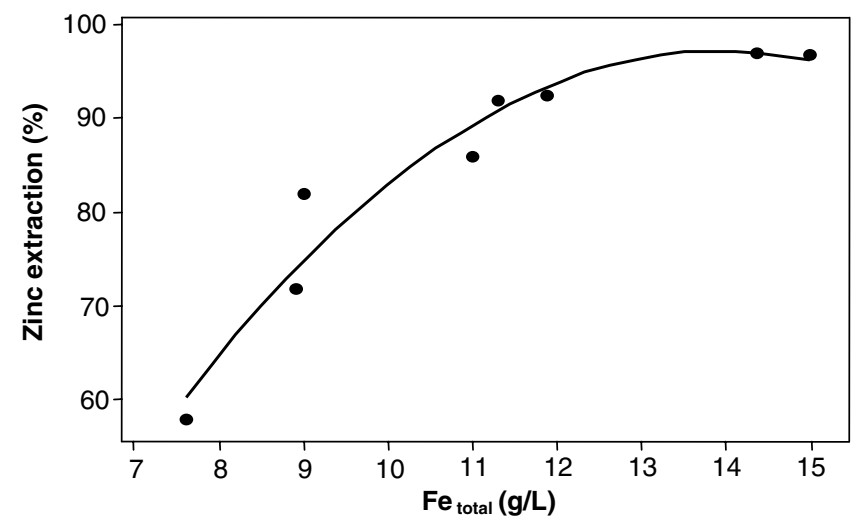

Fig. 7. Effect of $\mathrm{Fe}(\mathrm{II})$ concentration on the chemical leaching of partially bioleached $\mathrm{ZnS}$. Experimental conditions: $368 \mathrm{~K}\left(95^{\circ} \mathrm{C}\right), 10 \%$ solids, initial acidity $175 \mathrm{~g} / \mathrm{L}$. 
extractions at higher iron concentrations can be noticed. However, zinc extraction levels out after $12 \mathrm{~g} / \mathrm{L} \mathrm{Fe}$. Although the limits are not the same, these results are consistent with the work of Bobeck and Su (1985) which stated that zinc dissolution from sphalerite increases with the iron concentration up to $5.6 \mathrm{~g} / \mathrm{L}$ iron (Jin et al., 1984).

$\mathrm{Fe}(\mathrm{II})$ is also a product of the chemical dissolution of $\mathrm{ZnS}$ as shown by Eq. (1), Fig. 8 shows Fe(II) and Fe(III) concentration profiles during the chemical leaching experiment. It can be seen that iron was already in its reduced form at the beginning of the experiment. The reduction

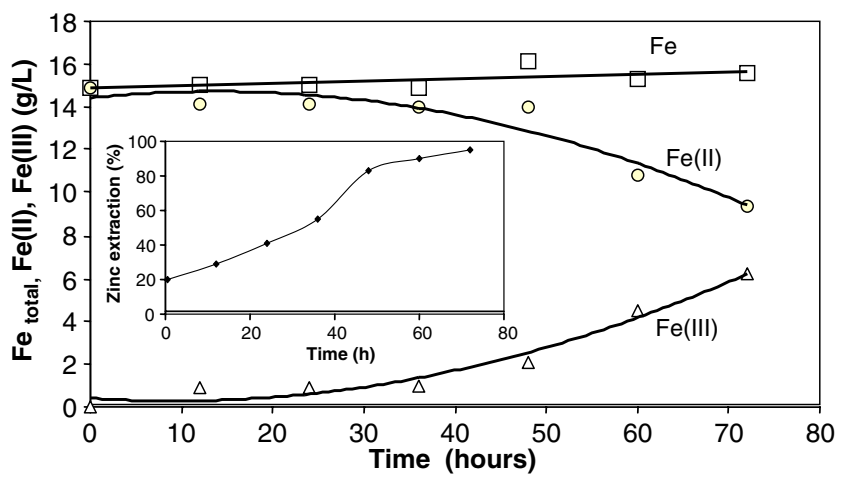

Fig. 8. Ferrous and ferric iron concentration profiles during chemical leaching of sphalerite. Experimental conditions: $368 \mathrm{~K}\left(95^{\circ} \mathrm{C}\right), 10 \%$ solids, initial $\mathrm{Fe}(\mathrm{III})$ concentration: $15 \mathrm{~g} / \mathrm{L}$; initial acidity: $175 \mathrm{~g} / \mathrm{L}, 72 \mathrm{~h}$ leaching time. of $\mathrm{Fe}$ (III) from the process solution accounted for around $20 \%$ zinc dissolution at the beginning of the leaching experiment (the first half hour). Following, Fe(III) concentration increased slowly and steadily as the reaction proceeded and iron(III) concentration reached $6 \mathrm{~g} / \mathrm{L}$ while $\mathrm{Fe}(\mathrm{II})$ content was reduced to $9.3 \mathrm{~g} / \mathrm{L}$, at the end of the experiment. This implies that after $30 \mathrm{~min}$ leaching time, all of the $\mathrm{Fe}(\mathrm{III})$, originally present in the leaching solution, reacted rapidly with the $\mathrm{ZnS}$, as already observed during the bioleaching studies (this is also another evidence of the importance of the indirect mechanism in the bioleaching of $\mathrm{ZnS}$ ). In

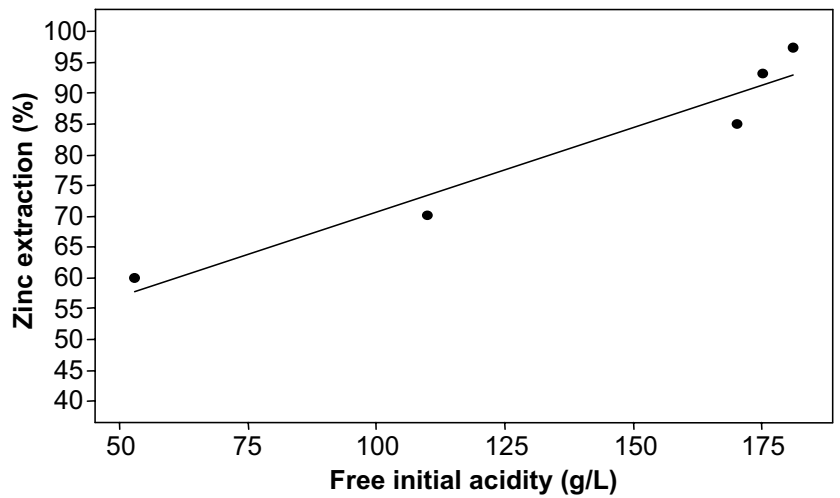

Fig. 10. Effect of initial free acidity on zinc extraction. Experimental conditions: $368 \mathrm{~K}\left(95^{\circ} \mathrm{C}\right)$; $10 \%$ solids; no iron addition; leaching time $72 \mathrm{~h}$.
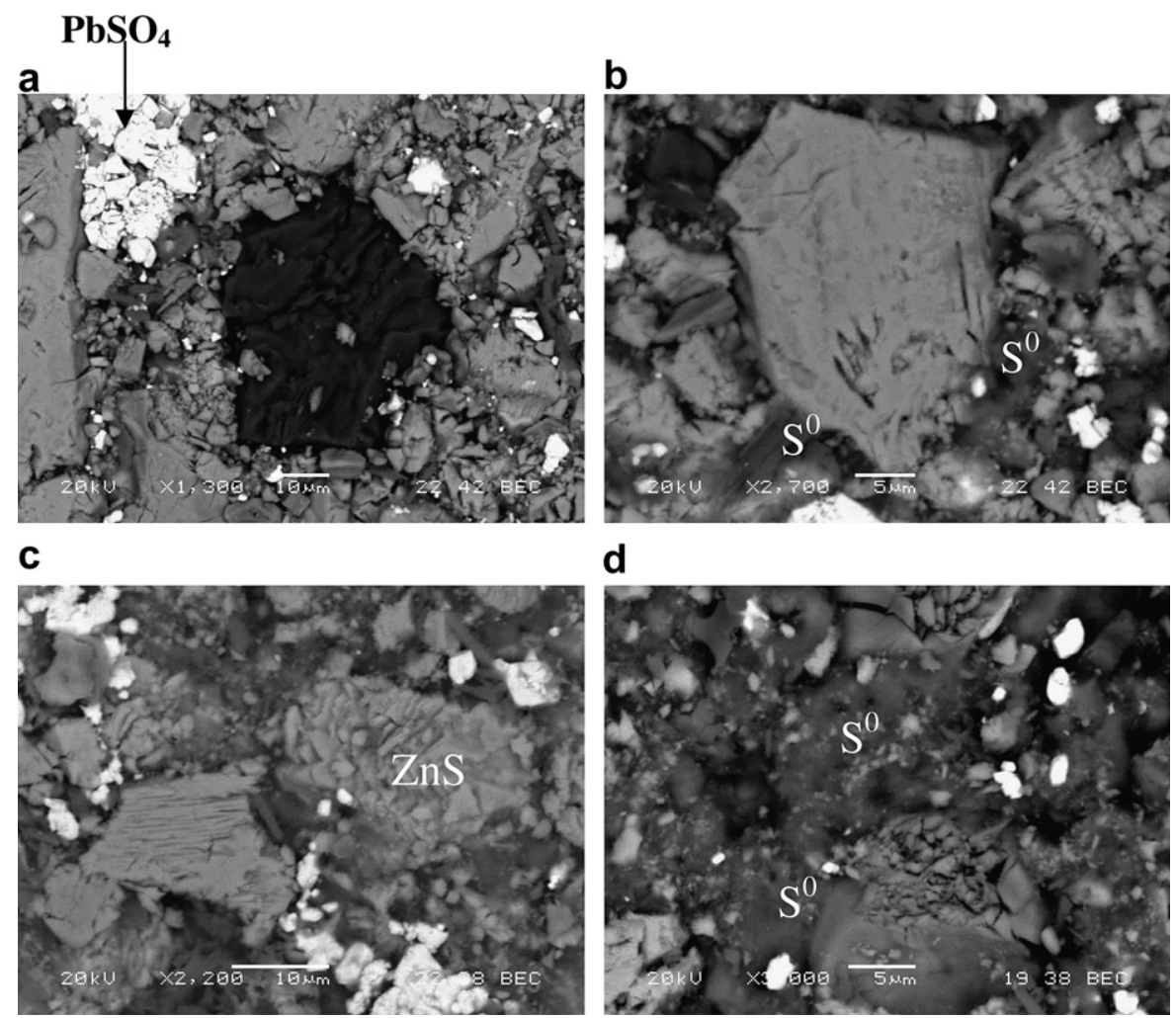

d

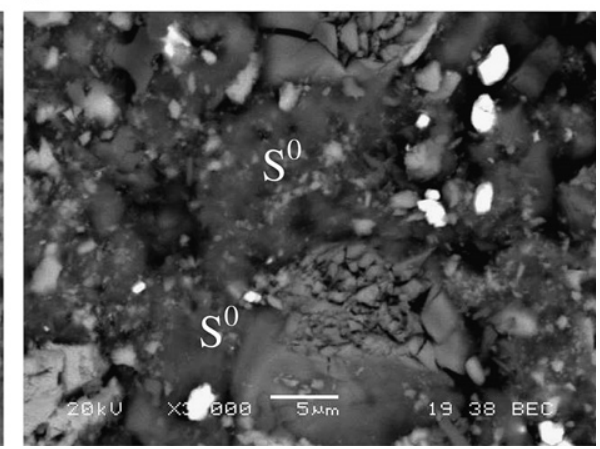

Fig. 9. SEM images of the zinc sulphide concentrate before (a) $12 \mathrm{~h}$; (b) $24 \mathrm{~h}$; (c) $36 \mathrm{~h}$ and (d) $48 \mathrm{~h}$ chemical leaching of the partially biooxidized zinc concentrate. 


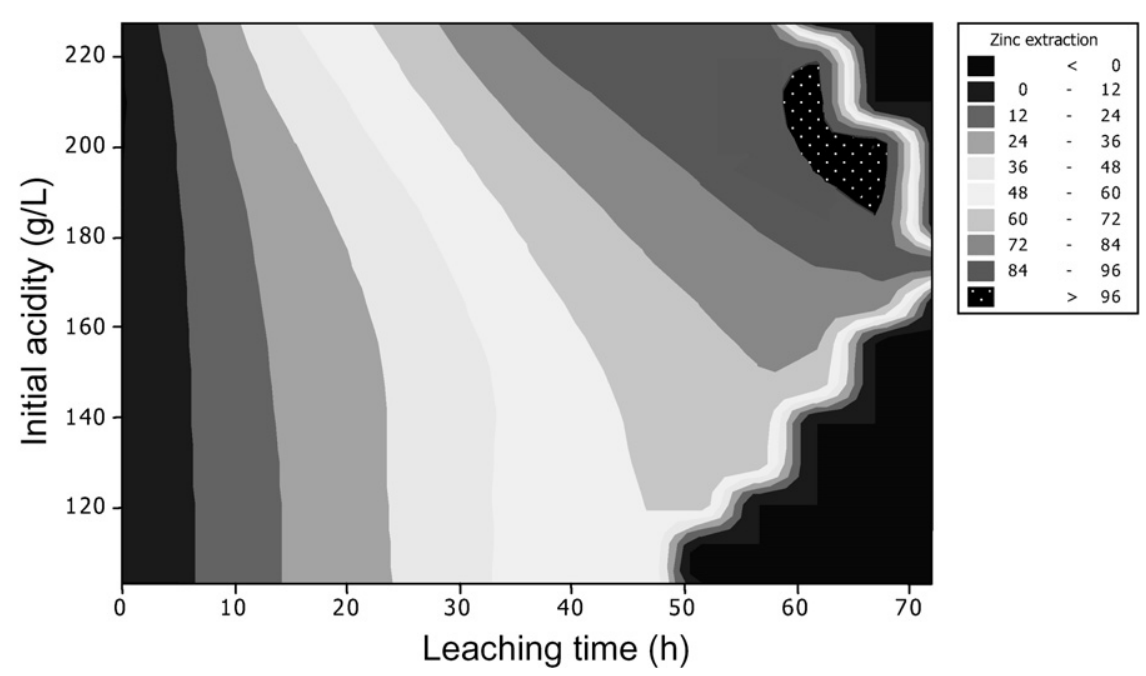

Fig. 11. Effect of residence time and initial free acidity on zinc extraction. Total iron $15 \mathrm{~g} / \mathrm{L}$.

addition, the box inside Fig. 8 shows that zinc dissolution stabilizes after $48 \mathrm{~h}$ of leaching which corresponds to over $80 \%$ zinc extraction. In this condition, most of sphalerite has been dissolved and sulphide sulphur was converted to elemental sulphur, apparently covering the mineral particles and reducing the leaching rate but not hindering $\mathrm{ZnS}$ dissolution (Fowler and Crundwell, 1999). The presence of elemental sulphur in the concentrate can be seen in Fig. 9. Fig. 9a is a SEM image of the sphalerite concentrate after $12 \mathrm{~h}$ leaching time. It can be seen that lead was converted to lead sulphate and elemental sulphur is yet to be seen. After 24 h (Fig. 9b), elemental sulphur can be noticed on some regions and its presence increases for longer leaching times (Fig. 9c and d).

As acid can leach sphalerite, the effect of the initial acidity on zinc dissolution is presented in Fig. 10. Fe(III) was not added to the leaching solution in this series of experiments. It can be seen that the zinc extraction increases with initial acidity. The largest extraction was $97.5 \%$ which corresponds to $181 \mathrm{~g} / \mathrm{L}$ initial acidity. Acidity values higher than $181 \mathrm{~g} / \mathrm{L}$ were not considered, since it would require acidity neutralisation which would not be recommended from a process point of view. These results are consistent with those observed by Babu et al. (2002) that observed an $80 \%$ zinc extraction $\left(\right.$ by $\mathrm{H}^{+}$) from a concentrate assaying $10 \%$ iron. Nevertheless, as the concentrate studied in the present work contained iron, the final solution contained $3.9 \mathrm{~g} / \mathrm{L} \mathrm{Fe}$, which suggests that part of the zinc extraction could be credited to iron produced during sphalerite dissolution and oxidized by oxygen. The effects of $\mathrm{Fe}$ (III) and acidity on the leaching kinetics of this concentrate is currently under study.

Summarizing, Fig. 11 shows the effect of both acidity and leaching time on zinc extraction. Zinc extractions higher than $96 \%$ were achieved for a minimum leaching time of $58 \mathrm{~h}$ and $180 \mathrm{~g} / \mathrm{L}$ free acidity i.e. similarly to those obtained in the conventional RLE process. Furthermore, it can also be concluded that the elemental sulphur layer formed during the chemical leaching did not hinder $\mathrm{ZnS}$ dissolution (Dutrizac and MacDonald, 1978).

Considering bioleaching and chemical leaching as integrated processes, the overall leaching time is reduced as compared to that observed by Pani et al. (2003) for the complete bioleaching of $\mathrm{ZnS}$; nevertheless the residence time is still relatively large. As a result, this route would be most suitable for small expansions in RLE plants, such as those in the range of 20,000 zinc tons per year, without the requirement of an increase in calcine production. This would be similar to the approach applied in direct leaching units such as the Kokkola plant (Finland) (Svens et al., 2003). Nevertheless, the proposed process could produce zinc solutions $(95 \mathrm{~g} / \mathrm{L})$ that can be directly fed to the industrial zinc electrolysis which facilitates its integration in the RLE process.

\section{Conclusions}

A new process comprising sphalerite bioleaching with mesophile microorganisms along with the chemical leaching of the zinc sulphide residue of the bioleaching step has been proposed. In the continuous bioleaching experiments with a $10 \%$ solids slurry, $30 \%$ zinc extractions could be achieved for $70 \mathrm{~h}$ residence time. Moreover, the microorganisms showed tolerance to $20 \mathrm{~g} / \mathrm{L} \mathrm{Fe}(\mathrm{III})$ and $45 \mathrm{~g} / \mathrm{L}$ $\mathrm{Zn}^{2+}$ in the process slurry. In the chemical leaching step, high zinc recoveries $(96 \%)$ were obtained in the presence of high acidity $(181 \mathrm{~g} / \mathrm{L})$. The results have demonstrated the likelihood of an environmentally friendly process to produce zinc extractions similar to those achieved by the roasting-leaching-electrolysis route.

\section{Acknowledgements}

The financial support for this work from "FINACIADORA DE ESTUDOS E PROJETOS - FINEP" and Votorantim Metais is gratefully appreciated. The 
"Conselho Nacional de Pesquisas - CNPq" scholarship to P.S. Pina is also acknowledged.

\section{References}

Babu, M.N., Sahu, K.K., Pandey, B.D., 2002. Zinc recovery from sphalerite concentrate by direct oxidative leaching with ammonium, sodium and potassium persulphates. Hydrometallurgy 64, 119-129.

Bobeck, G.E., Su, H., 1985. The kinetics of dissolution of sphalerite in ferric chloride solutions. Metallurgical Transactions B 16, 413-424.

Boon, M., 1996. Theoretical and experimental methods in the modelling of bio-oxidation kinetics of sulphide minerals. Department of Biochemical Engineering, Ph.D., Delft University of Technology, Delft, The Netherlands.

Boon, M., Snijder, G.S., Hansford, G.S., Heijnen, J.J., 1998. The oxidation kinetics of zinc sulphide with Thiobacillus ferrooxidans. Hydrometallurgy 48, 171-186.

Brierley, J.A., Brierley, C.L., 2001. Present and future commercial applications of biohydrometallurgy. Hydrometallurgy 59 (2-3), 233239.

Carmo, O.A., Lima, M.V., Guimarães, R.M.S., 2001. BIOX Process - the São Bento experience. In: Cimininelli, V.S.T., Garcia, O., Jr. (Eds.), International Biohydrometallurgy Symposium. Elsevier, Ouro Preto, Brazil, pp. 509-517.

Crundwell, F.K., 1988. The influence of the electronic structure of solids on the anodic dissolution and leaching of semiconducting sulphide minerals. Hydrometallurgy 21, 155-190.

Crundwell, F.K., 2001. How do bacteria interact with minerals? In: Cimininelli, V.S.T., Garcia, O., Jr. (Eds.), International Biohydrometallurgy Symposium. Elsevier, Ouro Preto, Brazil, pp. 149-157.

Daman, D., Leão, V.A., Silva, C.A., Gomes, F.J., 2002. Bioxidação de esfalerita brasileira por Acidithiobacills sp. In: Baltar, C.A.M., Oliveira, J.C.S., Barbosa, J.P. (Eds.), XIX Encontro Nacional de
Tratamento de Minérios e Metalurgia Extrativa. Recife, Brazil, pp. 76-82 (in Portuguese).

Dutrizac, J.E., MacDonald, R.J.C., 1978. The dissolution of sphalerite in ferric chloride solution. Metallurgical Transactions B 09, 543-551.

Feneau, C., 2002. Non-ferrous metals from Ag to Zn, Umicore, Brussels. 285pp.

Fowler, T.A., Crundwell, F.K., 1999. Leaching of zinc sulphide by Thiobacillus ferrooxidans: bacterial oxidation of the sulphur product layer increases the rate of zinc sulphide dissolution at high concentrations of ferrous iron. Applied and Environmental Microbiology 65 (12), 5285-5292.

Jin, Z.M., Warren, G.W., Henein, H., 1984. Reaction kinetics of the ferric chloride leaching of sphalerite - an experimental study. Metallurgical Transactions B 15B, 5-11.

Lacey, D.T., Lawson, F., 1970. Kinetics of the liquid-phase oxidation of acid ferrous sulfate by the bacterium Thiobacillus ferrooxidans. Biotechnology and Bioengineering 12, 29-50.

Nemati, M., Harrison, S.T.L., 1999. A comparative study on thermophilic and mesophilic biooxidation of ferrous iron. Minerals Engineering 13, $19-24$.

Nemati, M., Harrison, S.T.L., Hansford, G.S., Webb, C., 1998. Biological oxidation of ferrous sulphate by Thiobacillus ferrooxidans: a review on the kinetic aspects. Biochemical Engineering Journal 1 (1), 171-190.

Pani, C.K., Swain, S., Kar, R.N., Chaudhury, G.R., Sukla, L.B., Misra, V.N., 2003. Bio-dissolution of zinc sulfide concentrate in 1601 4-stage continuous bioreactor. Minerals Engineering 16, 1019-1021.

Schippers, A., Sand, W., 1999. Bacterial leaching of metal sulfides proceeds by two indirect mechanisms via thiosulfate or via polysulfides and sulfur. Applied and Environmental Microbiology 65 (1), 319-321.

Souza, A.D., 2005. Processo integrado: biolixiviação e lixiviação química na indústria do zinco. Master. Materials Engineering, Ouro Preto, Brazil Federal University of Ouro Preto (in Portuguese).

Svens, K., Kerstiens, K., Runkel, M., 2003. Recent experiences with modern zinc processing technology. Erzmetall 56, 94-103. 